\title{
A novel mechanism of tumor-induced thymic atrophy in mice bearing $\mathrm{H} 22$ hepatocellular carcinoma
}

This article was published in the following Dove Press journal: Cancer Management and Research

\author{
Sujun Sun* \\ Haiyu Ji* \\ Yingying Feng \\ Yu Kang \\ Juan Yu \\ Anjun Liu
}

Key Laboratory of Food Nutrition and Safety, Ministry of Education, College of Food Engineering and Biotechnology, Tianjin University of Science and Technology, Tianjin, China

*These authors contributed equally to this work
Correspondence: Anjun Liu

Key Laboratory of Food Nutrition and

Safety, Ministry of Education, College

of Food Engineering and Biotechnology,

Tianjin University of Science and

Technology, Number 29, I3th Street,

Tianjin Economic-Technological

Development Area, Tianjin 300457,

China

Tel +86226060 |39|

Fax +862260912390

Email laj@tust.edu.cn
Background: Thymic atrophy was discovered in tumor-bearing mice in recent years.

Methods: Flow cytometry was carried out including Annexin V-FITC/PI double staining, PI staining, Terminal dUTP nick-end labeling, CD3-FITC/CD19-PE and CD8-FITC/CD4-PE double staining. Enzyme-linked immunosorbent assay and polymerase chain reaction were also investigated. Results: According to our experiments, we demonstrated that no signs of apoptosis in thymocytes were found in $\mathrm{H} 22$-bearing mice, while the proportions of $\mathrm{CD}^{+} \mathrm{T}$ cells and $\mathrm{CD} 8^{+} \mathrm{T}$ cells in thymuses were remarkably increased, the opposite tendency was found in peripheral bloods, and only $\mathrm{CD}^{+} \mathrm{CD}^{+} \mathrm{T}$ cells were discovered in $\mathrm{H} 22$ solid tumors. We further discovered that the level of thymosin alpha $1(\mathrm{~T} \alpha 1)$ and the expression of $W n t 4$ in thymus of H22-bearing mice were significantly improved than control, which indicated the active proliferation and differentiation of thymocytes. Our study revealed that $\mathrm{CD} 8^{+} \mathrm{T}$ cells could not effectively eliminate $\mathrm{H} 22$ cells independently when $\mathrm{CD} 4^{+} \mathrm{T}$ cells were suppressed by tumors, while the body would only enhance the differentiation and maturation of T cells in thymuses and release them to solid tumor to reinforce antitumor immunocompetence, leading to a vicious cycle which finally led to thymic atrophy.

Conclusion: Our data propose a novel mechanism of tumor-induced thymic atrophy regulated by abnormal immunoreaction and may provide new ideas for the immunotherapy of tumors.

Keywords: thymic atrophy, T cells subsets, over-differentiation, H22 tumor

\section{Introduction}

As a primary lymphoid organ, the thymus provides a highly specialized microenvironment for the differentiation and maturation of immunocompetent $\mathrm{T}$ lymphocytes, which consists of an outer cortex and inner medulla. ${ }^{1-5}$ Thymosin alpha 1 (T $\left.\alpha 1\right)$, a biologically active peptide mainly existing in thymic epithelial cells, can enhance cellular immune responses, modulate secretion of cytokines, and block steroid-induced apoptosis of thymocytes. ${ }^{6-8}$ Wnt4 has recently been shown to regulate multiple developmental processes reflected by accumulating the downstream molecule $\beta$-catenin. ${ }^{9}$

$\mathrm{T}$ lymphocytes including $\mathrm{CD} 8^{+} \mathrm{T}$ cells and $\mathrm{CD}^{+} \mathrm{T}$ cells have been considered as the main protagonists in orchestrating the anti-tumor response. ${ }^{10-13} \mathrm{CD} 8^{+} \mathrm{T}$ cells impart cytolytic activity and cytokine expression in anti-tumor immunity, ${ }^{14}$ and previous studies have shown that patients bearing tumors would universally have better outcomes when treated with massive infiltration of $\mathrm{CD} 8^{+} \mathrm{T}$ cells. ${ }^{15} \mathrm{CD} 4^{+} \mathrm{T}$ cells play an important role in modulating anti-tumor immune response via activating and expanding $\mathrm{CD}^{+} \mathrm{T}$ cells, recruiting and activating natural killer cells and macrophages, and secreting IFN- $\gamma{ }^{16-18}$

Cancer has become a major concern for human health due to the low cure rate and high mortality. ${ }^{19,20}$ Hepatocellular carcinoma, the fifth most common cancer and third 
leading cause of cancer death worldwide, is mainly caused by the hepatitis B virus. ${ }^{21-24}$ Thymic atrophy is accompanied with tumorigenesis which finally leads to the perturbed output of mature T cells in hosts, ${ }^{25-29}$ which suggests that the tumor is one of the major factors resulting in thymic involution, ${ }^{30}$ and tumor-induced immunosuppression is responsible for the failure of cancer therapy. ${ }^{31}$

Given the immune function of the thymus and $\mathrm{T}$ cells, it is of great value to investigate the possible mechanism of tumor-induced thymic atrophy. It has been reported that apoptosis and block in $\mathrm{T}$ cell maturation are responsible for thymic atrophy in tumor-bearing hosts, ${ }^{32}$ while in our study, we focused on the population and cellular condition of T cells in H22-bearing mice and demonstrated another possible mechanism of thymic atrophy.

\section{Materials and methods Materials}

T $\alpha 1$ was synthesized by Beijing Protein Innovation Co. (Beijing, China) (purity of $>99 \%$ based on HPLC). Fetal calf serum was obtained from Hangzhou Sijiqing Co (Zhejiang, China). CD19-PE, CD3-FITC, CD4-PE, and CD8-FITC antimouse antibodies were from Tianjin Sungene Biotech Co., Ltd (Tianjin, China). One Step TUNEL Apoptosis Assay Kit and Annexin V-FITC Apoptosis Detection Kit were purchased from Beyotime Biotechnology Co., (Shanghai, China). Propidium iodide (PI) was provided by Sigma-Aldrich Co. (St Louis, MO, USA). All other chemicals and agents were of analytical grades.

\section{Animals and cells}

Kunming SPF mice (female, 20-22 g, 8-week-old) were purchased from the Department of Experimental Animals, Academy of Military Medical Science, Beijing, and acclimatized to the facility for 1 week prior to experiments. These animals were housed under pathogen-free conditions at a relative humidity $(50 \pm 5 \%)$ and controlled temperature $\left(20^{\circ} \mathrm{C}-25^{\circ} \mathrm{C}\right)$, and they were allowed free access to tap water and fed with a standard pellet diet on a $12 \mathrm{~h}$ light/dark cycle. All experimental procedures following the National Institutes of Health guidelines for the care and use of laboratory animals were approved by the Local Ethics Committee for Animal Care and took place at Tianjin University of Science and Technology. H22 hepatoma cells were purchased from Shanghai Institute for Biological Sciences (Chinese Academy of Sciences, Shanghai, China) and maintained in RPMI 1640 medium supplemented with $10 \%$ fetal bovine serum at $37^{\circ} \mathrm{C}$ in a humidified incubator containing $5 \% \mathrm{CO}_{2}$.

All mice were randomly divided into two groups. Mice in the model group were implanted with $\mathrm{H} 22$ hepatoma cells in the right forelimb armpit with $0.2 \mathrm{~mL}$ of $5 \times 10^{6}$ cells under sterile conditions, and empty treatments were done in the control group. Control and model groups received saline solution orally throughout the experimental period and mice were sacrificed to provide experiment samples for further research after 3 weeks' administration.

Thymus index $(\%)=$ average weight of thymus / (average body weight) $\times 100$

\section{H\&E staining}

Thymuses of mice in each group were embedded with paraffin and stained with H\&E using standard procedures for the structure observation. Thymocytes from different groups were obtained through a steel mesh under aseptic conditions, fixed with paraformaldehyde, and stained with $\mathrm{H} \& \mathrm{E}$ for morphologic examination of individual cells. The staining results were observed using microscopy.

\section{Annexin V-FITC/PI double staining}

The apoptosis in mice thymocytes of each group was examined using a double staining method with Annexin V-FITC/ PI. According to the manufacturer's instructions, thymic cell suspension was prepared and washed with cold PBS, Annexin V-FITC was added and incubated for $10 \mathrm{~min}$ at room temperature away from light after which PI was added. Stained cells were analyzed by FACScalibur flow cytometry (BD Biosciences, San Jose, CA, USA).

\section{Analysis of cell cycle distribution}

The cell cycle distribution was analyzed through the flow cytometry detection method. Thymic cell suspensions in different groups were prepared and fixed in $75 \%$ ethanol at $4^{\circ} \mathrm{C}$ overnight. After washing with PBS, the cells were stained with PI working solutions ( $0.1 \%$ TritonX-100, $100 \mathrm{mg} / \mathrm{mL}$ PI, $0.01 \mathrm{mg} / \mathrm{mL}$ RNase) for $30 \mathrm{~min}$ in the dark. Twenty thousand events of each sample were acquired by CellQuest Pro and analyzed by Modifit, and cell cycle distribution was assessed by DNA content.

\section{TUNEL assay}

TUNEL assays were performed to detect apoptotic cells in thymuses. Thymocytes were washed twice before being suspended in permeabilization solution (10 mg sodium citrate and $10 \mu \mathrm{L}$ Triton $\mathrm{X}-100$ in $10 \mathrm{~mL}$ sterile water) for $2 \mathrm{~min}$ on ice. After permeabilization, samples were washed with $1 \mathrm{~mL}$ PBS and stained with TUNEL Reaction Mixture for $1 \mathrm{~h}$ protected from light. Positive control samples were treated with $10 \mu \mathrm{L}$ DNase I before staining. After staining, samples were simultaneously assessed using a flow cytometer. 


\section{Detection of T lymphocyte subpopulation}

Lymphocyte subpopulations in peripheral blood and $\mathrm{H} 22$ tumors were tested with CD3-FITC/CD19-PE and CD8FITC/CD4-PE reagents. Peripheral blood of each group was collected from the orbital venous plexus, and solid tumors were obtained from $\mathrm{H} 22$-bearing mice. The tubes containing $100 \mu \mathrm{L}$ samples $\left(1 \times 10^{7}\right.$ cells $\left./ \mathrm{mL}\right)$ were mixed with antibodies, followed by 15 min away from light. Then red blood cells were removed by adding RBC lysis buffer, and finally these samples were resuspended in $1 \times \mathrm{PBS}$ and evaluated by flow cytometer.

$\mathrm{CD}^{+} \mathrm{T}$ cell and $\mathrm{CD} 8^{+} \mathrm{T}$ cell population in thymus was tested with CD8-FITC and CD4-PE reagents. Thymocyte suspensions were produced by forcing the thymus through a wire-mesh screen and diluting with PBS. Following centrifugation (1,500 rpm, $5 \mathrm{~min}$ ), lymphocytes were collected and then incubated with the antibodies for $15 \mathrm{~min}$ in the dark. Thymocytes were analyzed after PBS washing on a flow cytometer and analyzed with CellQuest software.

\section{Detection of T $\alpha$ I levels}

The T $\alpha 1$ levels in serum and thymuses of mice were analyzed through ELISA method. The water-soluble protein extracts of thymuses and serum with coating buffer were inoculated in a 96-well Elisa plate at $4^{\circ} \mathrm{C}$ overnight, the mixtures were transferred and the wells were incubated with blocking buffer for $1 \mathrm{~h}$ at $37^{\circ} \mathrm{C}$. After washing with PBST, levels of T $\alpha 1$ in thymuses and serum of mice were detected by adding rabbit anti-To1 antibody (Bioss Biotechnology Co., Beijing, China; 1:200) and goat anti-rabbit IgG antibody (Bioss Biotechnology Co.; 1:200) respectively. The chemosynthetic To1 was used as standard. The absorbance was read at $450 \mathrm{~nm}$ with a reference of $630 \mathrm{~nm}$ with BioRad Model 680 Microplate Reader. (Bio-Rad Laboratories Inc., Hercules, CA, USA)

\section{Expression of Wnt4 in thymocytes}

The primer pairs used are shown in in Table 1. RNA was isolated from thymocytes using Trizol reagents (Thermo Fisher Scientific, Waltham, MA, USA) according to the manufacturer's instructions. A total of $1 \mu \mathrm{g}$ of RNA was

Table I Primer sequences used in RT-PCR

\begin{tabular}{ll}
\hline Primers & Sequence \\
\hline Wnt4 forward & $5^{\prime}$ TGTCATCGGTGGGCAGCAT 3' \\
Wnt4 reverse & 5'CCTGCCAGCCTCATTGTTGTG3' $^{\prime}$ \\
$\beta$-actin forward & $5^{\prime}$ ACACCCGCCACCAGTTCG 3' \\
$\beta$-actin reverse & $5^{\prime}$ TTCTGACCCATTCCCACCAT3' \\
\hline
\end{tabular}

transcribed into cDNA using a PrimeScript RT reagents kit (Takara Biomedical Technology Co., Beijing, China). Quantitative real-time PCR was performed by Q-PCR tower 2.0 system (Analytik Jena AG, Jena, Germany) with the following conditions: $95^{\circ} \mathrm{C}$ for $2 \mathrm{~min}, 40$ cycles of $95^{\circ} \mathrm{C}$ for $10 \mathrm{~s}$, $60^{\circ} \mathrm{C}$ for $32 \mathrm{~s}, 72^{\circ} \mathrm{C}$ for $30 \mathrm{~s}$.

\section{Statistical analysis}

All values from the present study are expressed as mean \pm SD from at least three independent experiments, and each one was performed in triplicate. Statistical analysis was carried out using one-way ANOVA test followed by Student's $t$-test (SPSS 19.0; IBM Corporation, Armonk, NY, USA). The level of significance was set at $p<0.01$.

\section{Results \\ Results of thymus weights in mice}

As shown in Table 2, the body weights of tumor-bearing mice showed no significant difference from the control group, while the thymus weights and thymus indices were obviously decreased, which proved that the solid tumors in vivo could induce thymic atrophy of the host.

\section{Results of H\&E staining}

Pathological changes of mice thymuses were observed by H\&E staining. As shown in Figure 1A, thymuses of normal mice were well structured with obvious boundary of the cortex and medulla, whereas the epithelial networks of thymuses in H22-bearing mice were damaged and discontinued, and the extracellular matrix was significantly increased. The staining results of thymocytes are shown in Figure 1B, thymocytes of tumor-bearing mice remained integral and formed round, and showed no obvious difference compared to the control group.

\section{Apoptosis cells tested by Annexin V/PI assay}

Annexin V-FITC/PI staining was conducted on thymocytes to determine the cellular state, permeability change, and disruption of cell membrane in early apoptosis would lead phospholipidine serine (PS) exposed to the external surface, which makes

Table 2 Effects of solid tumors on thymuses in mice

\begin{tabular}{|c|c|c|c|c|}
\hline Groups & $\begin{array}{l}\text { Tumor } \\
\text { weight (g) }\end{array}$ & $\begin{array}{l}\text { Body } \\
\text { weight } \\
\text { (g) }\end{array}$ & $\begin{array}{l}\text { Thymus } \\
\text { weight } \\
\text { (mg) }\end{array}$ & $\begin{array}{l}\text { Thymus } \\
\text { index } \\
\text { (mg/g) }\end{array}$ \\
\hline Control & - & $27.25 \pm 1.07$ & $69.28 \pm 4.36$ & $2.5 \mathrm{I} \pm 0.23$ \\
\hline Model & $2.28 \pm 0.42$ & $26.65 \pm 1.21$ & $36.64 \pm 2.38 * *$ & $1.32 \pm 0.12^{* *}$ \\
\hline
\end{tabular}


it easy to combine with annexin V bearing FITC, PI has poor membrane permeability and only apoptotic cells in late stage or necrotic cells can be stained. As shown in Figure 2, there was almost $90 \%$ of thymocytes of mice in both control and model groups in quadrant 3 , indicating that $T$ cells in mice thymuses of these two groups were normal cells and the nearly $10 \% \mathrm{~T}$ cells were found to be apoptotic mainly due to the process of grinding for preparation of the thymocytes' suspension.

\section{Cell cycle distribution of thymocytes}

PI could bind to DNA and RNA in cells, and only DNA would be stained after RNA removal by RNase. The distribution of cell cycle could be reflected by fluorescence intensity through flow cytometry. As shown in Table 3, there was no significant

A
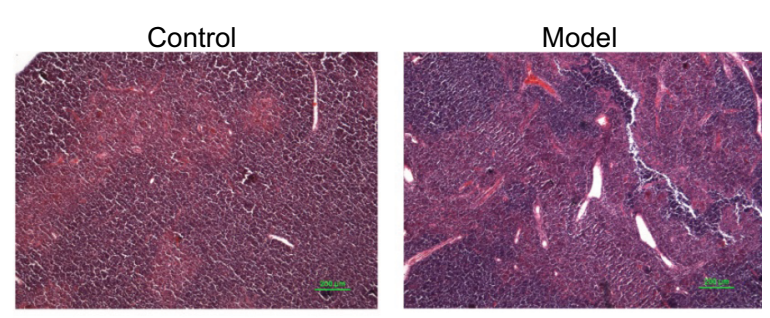

B
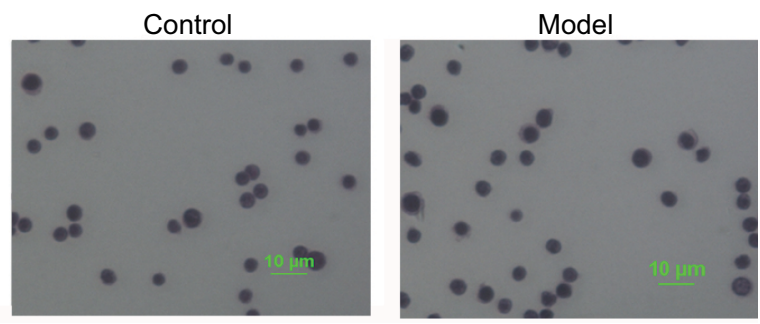

Figure I Results of H\&E staining.

Notes: (A) Thymus paraffin section; (B) T cells in thymus. difference found in cell cycle distribution of thymocytes in tumor-bearing mice compared to the control group, which indicated the good condition of cell shape and growth.

\section{Thymocyte apoptosis detection by TUNEL staining}

Cell apoptosis activated DNA endonuclease activity by cutting the genomic DNA, and the exposed 3'-OH was combined with dUTP marked by FITC with the TdT catalyst, and cells were tested by flow cytometry. As shown in Figure 3, there were no TUNEL positive thymocytes found in mice of both control and model groups, which indicated that tumors did not result in DNA degradation of thymocytes.

\section{The differentiation of $\mathrm{CD}^{+}$and $\mathrm{CD}^{+} \mathrm{T}$ cells in thymuses}

$\mathrm{CD}^{+}$and $\mathrm{CD}^{+} \mathrm{T}$ cells are of critical importance in the execution of immune response on hepatocarcinogenesis. As shown in Figure 4, thymuses of $\mathrm{H} 22$-bearing mice showed lower proportions of $\mathrm{CD}^{+} \mathrm{CD}^{+} \mathrm{T}$ cells and higher proportions of $\mathrm{CD}^{+} \mathrm{CD}^{-}$and $\mathrm{CD}^{-} \mathrm{CD}^{+} \mathrm{T}$ cells $(p<0.01)$, which indicated that $\mathrm{H} 22$ solid tumors could accelerate the development, differentiation, and maturation of $\mathrm{T}$ cells in the thymus.

Table 3 Distribution of cell cycle and apoptosis rate of thymocytes

\begin{tabular}{lllll}
\hline Groups & G0/GI (\%) & S (\%) & G2/M (\%) & Apoptosis (\%) \\
\hline Control & $86.33 \pm 1.99$ & $6.35 \pm 1.84$ & $7.34 \pm 0.62$ & $0.50 \pm 0.41$ \\
Model & $87.28 \pm 1.20$ & $4.83 \pm 1.37$ & $7.89 \pm 0.97$ & $0.91 \pm 0.67$ \\
\hline
\end{tabular}

A

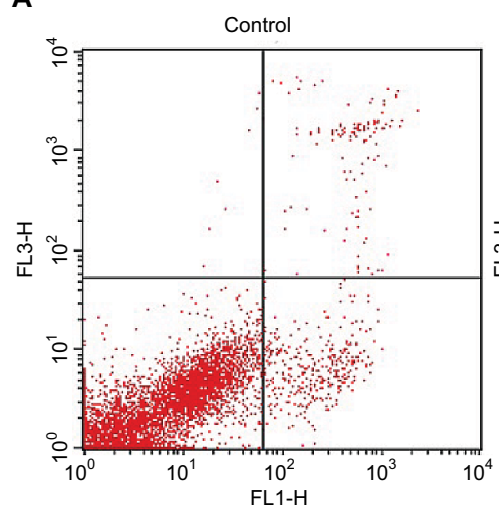

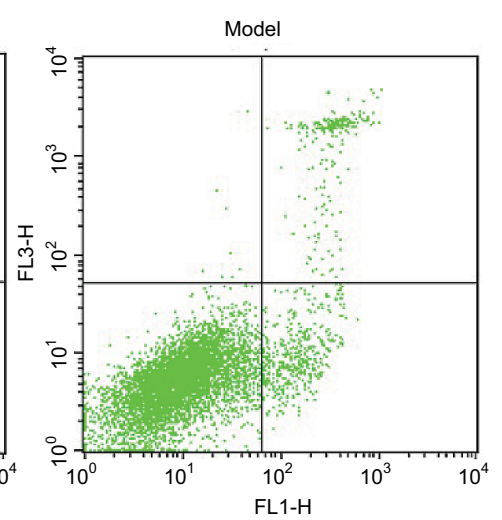

B

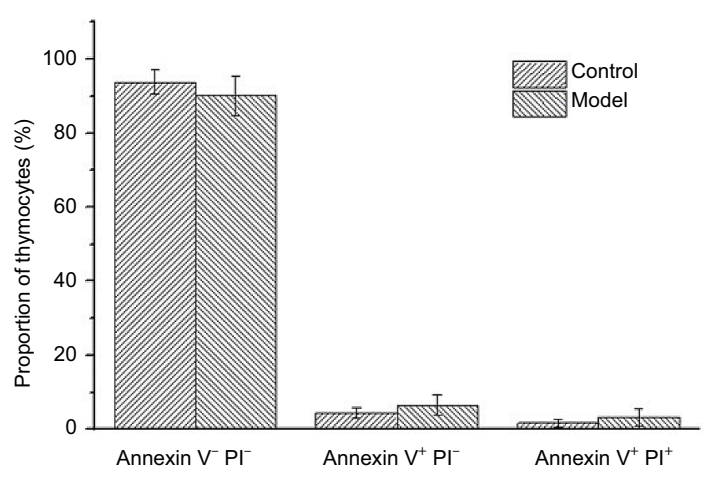

Figure 2 Annexin V-FITC/PI staining results of T cells in thymuses.

Notes: (A) Annexin $\mathrm{V}^{-} \mathrm{PI}^{-}$(quadrant 3), Annexin $\mathrm{V}^{+} \mathrm{Pl}^{-}$(quadrant 4), and Annexin $\mathrm{V}^{+} \mathrm{Pl}^{+}$(quadrant $\mathrm{I}$ ) represent normal $\mathrm{T}$ cells, cells in early apoptosis, and late apoptosis. (B) Proportion of thymocytes in different stages.

Abbreviation: PI, propidium iodide. 
A

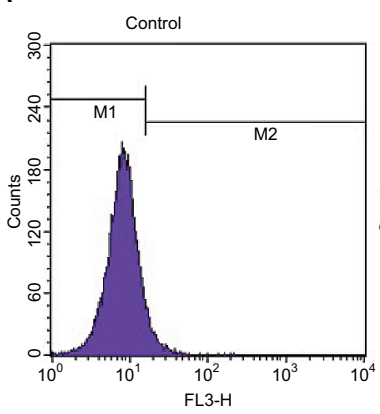

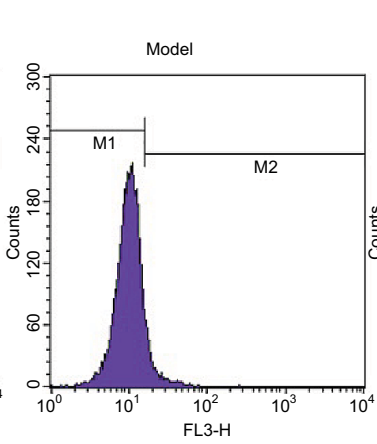

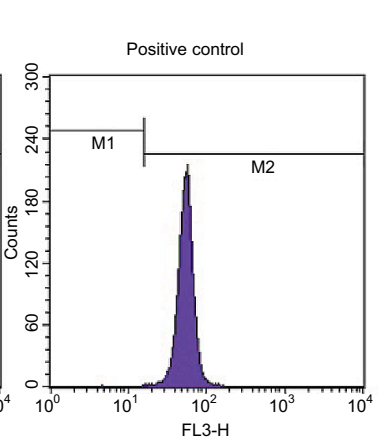

B

Figure 3 Results of TUNEL staining on thymocytes.

Notes: (A) MI and M2 represent the normal and apoptotic thymocytes; (B) proportion of thymocytes in different conditions.

A

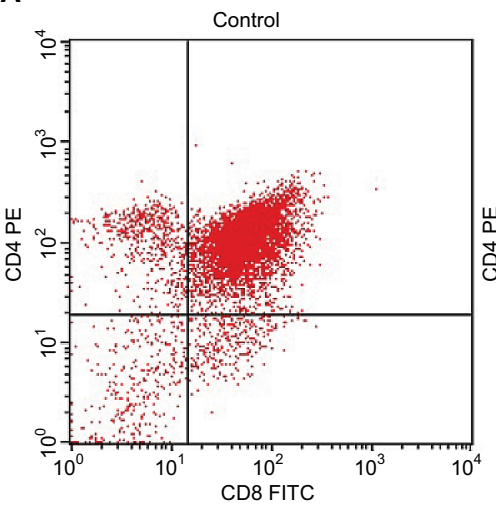

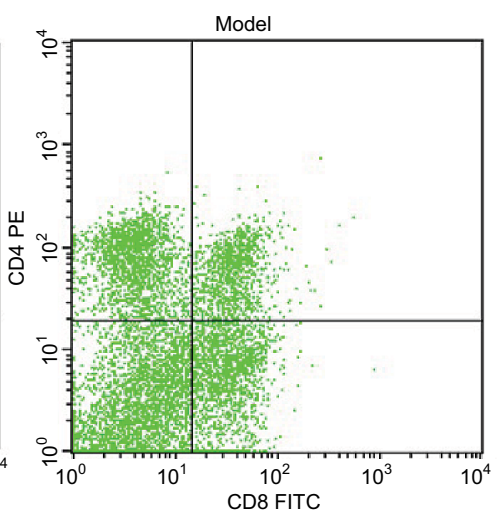

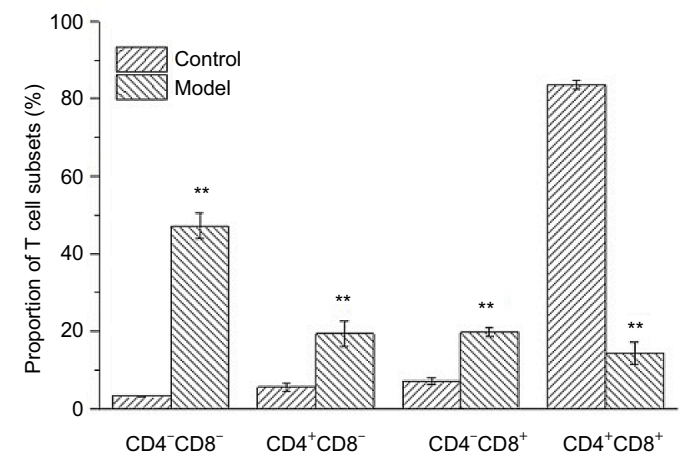

Figure 4 Changes in the proportions of lymphocyte subsets.

Notes: (A) Upper left (quadrant 2) means the thymocytes combined with PECD4+ antibodies, Upper right (quadrant I) means thymocytes which can be combined with both antibodies, Lower left (quadrant 3 ) means the cells combined with no antibodies, Lower right (quadrant 4) means the cells combined with FITC-CD8 ${ }^{+}$antibodies. (B) Proportions of T lymphocyte subsets in normal and $\mathrm{H} 22$-bearing mice. ${ }^{* *} p<0.01$ vs control group.

\section{Proportions of lymphocyte subsets in peripheral blood and solid tumor}

As shown in Table 4, the proportions of $\mathrm{T}$ cell subsets in peripheral blood of H22-bearing mice were significantly decreased $(p<0.01)$ compared to the control group, and large amounts of tumor-infiltrating $\mathrm{CD} 3{ }^{+} \mathrm{CD} 8^{+} \mathrm{T}$ cells were discovered in $\mathrm{H} 22$ solid tumors, suggesting that $\mathrm{H} 22$ cells' proliferation in vivo would induce $\mathrm{T}$ cells' aggregation in solid tumor with lower immunocompetence. While the noticeable increase $(p<0.01)$ in the proportion of CD19+ $\mathrm{B}$ cells in peripheral blood might indicate that some distinct tumor-related antibodies are existed in tumor hosts.

\section{Levels of T $\alpha \mathrm{I}$ in serum and thymuses of mice}

As shown in Table 5, the levels of T $\alpha 1$ in serum and thymuses of H22-bearing mice were both significantly increased $(p<0.01)$ compared to the control group, which indicated that $\mathrm{H} 22$ solid tumors could promote the secretion of T $\alpha 1$ from thymuses, and enhance the vitality of
Table 4 Percentages of lymphocyte subsets in peripheral blood and tumors in different groups (mean \pm standard deviation, $\mathrm{n}=10$ )

\begin{tabular}{llll}
\hline \multirow{2}{*}{$\begin{array}{l}\text { Lymphocyte } \\
\text { subsets }\end{array}$} & \multicolumn{2}{l}{ Lymphocytes in blood } & \multirow{2}{*}{$\begin{array}{l}\text { Tumor-infiltrating } \\
\text { lymphocytes }\end{array}$} \\
\cline { 2 - 3 } & Control & Model & \\
\hline CDI9+ B cells/ (\%) & $18.70 \pm 2.33$ & $27.18 \pm 5.0 * *$ & $1.28 \pm 0.39$ \\
$\mathrm{CD}^{+}$T cells/ (\%) & $49.19 \pm 4.96$ & $36.53 \pm 2.62 * *$ & $39.29 \pm 1.93$ \\
$\mathrm{CD} 4^{+}$T cells/ (\%) & $39.36 \pm 4.52$ & $27.18 \pm 3.02 * *$ & $0.10 \pm 0.04$ \\
$\mathrm{CD} 8^{+}$T cells/ (\%) & $10.365 \pm 2.64$ & $5.97 \pm 1.70 * *$ & $30.77 \pm 4.62$ \\
\hline
\end{tabular}

Note: ${ }^{* *} p<0.01$ vs control group.

Table 5 Levels of $T \alpha I$ in serum and thymuses of mice in each group (mean $\pm S D, n=10$ )

\begin{tabular}{lll}
\hline Groups & Levels of T $\alpha \mathbf{l}$ \\
\cline { 2 - 3 } & Serum/ $(\mu \mathrm{g} / \mathrm{mL})$ & Thymuses/ $(\mu \mathrm{g} / \mathrm{g})$ \\
\hline Control & $10.58 \pm 1.24$ & $1.26 \pm 0.1 \mathrm{I}$ \\
Model & $27.49 \pm 2.24^{* *}$ & $3.68 \pm 0.14^{* *}$ \\
\hline
\end{tabular}

Note: $* * p<0.01$ vs control group.

Abbreviation: $T \alpha I$, thymosin alpha I.

thymic cells, finally resulting in the over-differentiation of $T$ cells, which would contribute to thymic atrophy in the host. 


\section{Expression of Wnt4 in thymocytes of $\mathrm{H} 22$-bearing mice}

As shown in Figure 5, mRNA levels of Wnt4 in thymocytes of H22-bearing mice were significantly increased $(p<0.01)$ compared to the control group, and $\beta$-actin which was used as loading control also showed higher values in the model group, suggesting that thymocytes in tumor-bearing mice were proliferous and active.

\section{Discussion}

Cancer occurrence depends on a complex process of multiple factors and stages. The inhibition effects of tumor cells on immune reactivity were responsible for the disorder of the immune system in the tumor host, which would lead to the lower cure rate. ${ }^{33}$ Large studies have suggested that organisms could resist the malignant tumor spontaneously with mostly cellular immunity mediated by $\mathrm{T}$ lymphocytes ${ }^{34,35} \mathrm{~T}$ cell differentiation status and the metabolic properties of T cells may play an important role in regulating their anti-tumor functionality. ${ }^{36}$

The thymus, as the dominant source of cellular immunity, provides a suitable microenvironment for T cells' differentiation and maturation. Thymic atrophy would seriously impact the body's immunity and disturb homeostasis, and generally occurs among the elderly ${ }^{37}$ While recent studies have shown that the presence of cancer could also accelerate the involution of thymus in tumor-bearing host, some scholars believe that some factors or antigens released from malignant tumors would have toxic or stimulating effects on the thymus and induce the apoptosis of thymocytes, thus leading to thymic atrophy. ${ }^{38-41}$ The immunodepression of anti-tumor activity caused by thymic atrophy would be beneficial to immunoevasion of tumor cells. ${ }^{42,43}$

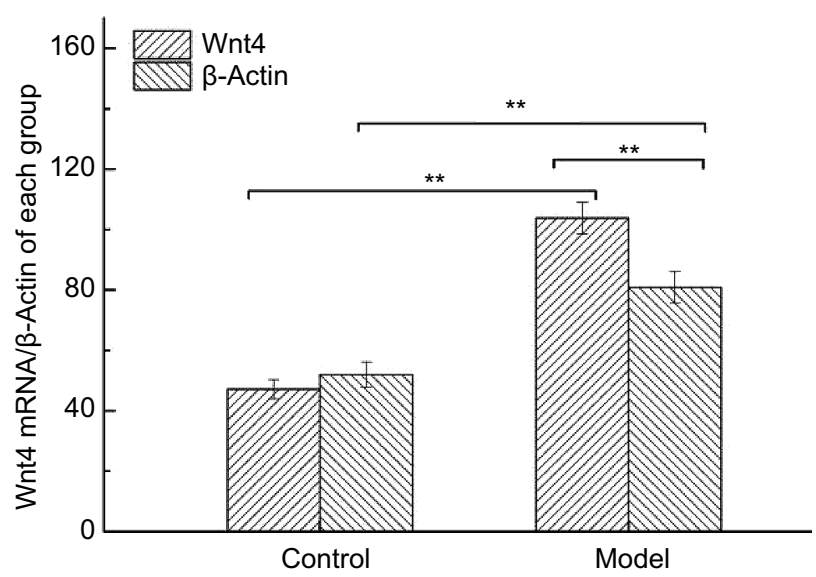

Figure 5 The mRNA levels of Wnt4 in thymus tissues from each group. Note: ${ }^{* *} p<0.01$ vs control group.
Our previous studies showed that the indexes of thymuses in H22-bearing mice were significantly decreased in contrast to normal mice. Thus, we propose a hypothesis that the mechanism of thymic atrophy in tumor-bearing mice is over-differentiation of thymocytes as a way of initiating immune response. T cells in the thymus would continuously differentiate and mature to protect the body during tumorigenesis, while even mature $\mathrm{T}$ cells without activation could not effectively induce tumor cell apoptosis, resulting in a higher differentiation and maturation rate than proliferation rate of thymocytes, and eventually leading to thymic atrophy.

Therefore, we established an H22-bearing mice model in the present experiment and used the thymuses to investigate the mechanisms of thymic atrophy caused by $\mathrm{H} 22$ solid tumors. In order to detect the condition of thymocytes in H22-bearing mice, we employed H\&E staining, Annexin V/FITC and PI staining, cell cycle detection, and TUNEL staining assays. Results showed that there were no signs of apoptosis in thymocytes of H22-bearing mice (Figure 1B, Figure 2-4, Table 3), while the structure of the thymus was significantly destroyed due to the thymic atrophy (Figure 1A). These results suggested a distinct direction on the mechanism of thymic atrophy in tumor-bearing mice, which guided us to further determine the cellular conditions and subpopulations of thymocytes to study this novel mechanism.

The proportions of $\mathrm{T}$ lymphocyte subsets in thymuses, peripheral blood, and solid tumors were detected to further research the possible mechanism of thymic atrophy in H22-bearing mice. Results showed that the proportions of $\mathrm{CD}^{+} \mathrm{T}$ cells and $\mathrm{CD} 8^{+} \mathrm{T}$ cells in thymuses of $\mathrm{H} 22$-bearing mice were markedly increased compared to controls (Figure 4), while the opposite tendencies were found in peripheral blood, and only $\mathrm{CD} 3^{+} \mathrm{CD} 8^{+} \mathrm{T}$ cells were discovered in solid tumors (Table 4), consistent with Kuss et al's and Saito et al's research on patients suffering from different types of cancer. ${ }^{44,45}$ As we know, $\mathrm{CD}^{+} \mathrm{T}$ cells play an important role in recognizing tumor epitopes and eliciting tumor rejection, ${ }^{46}$ while $\mathrm{CD} 4{ }^{+} \mathrm{T}$ cells would assist the cytotoxic activity of $\mathrm{CD} 8^{+} \mathrm{T}$ cells in limiting tumor cell growth and the generation of memory $\mathrm{CD} 8^{+} \mathrm{T}$ cells for preventing tumor recurrences. ${ }^{47}$ Our results indicated that $\mathrm{CD} 4^{+} \mathrm{T}$ cells might be suppressed by $\mathrm{H} 22$ cells, and $\mathrm{CD} 8^{+} \mathrm{T}$ cells could not effectively eliminate tumors without the help of $\mathrm{CD} 4^{+} \mathrm{T}$ cells, which resulted in the growth of tumors with $\mathrm{CD} 8^{+} \mathrm{T}$ cells gathered around, while the body would only enhance the differentiation and maturation of $\mathrm{T}$ cells in thymuses, finally leading to thymic atrophy. 
T $\alpha 1$, a biological response modifier, could enhance the immune system through promoting differentiation and maturation of $\mathrm{T}$ lymphocytes. ${ }^{48,49} \mathrm{Wnt} 4$ has been proven to be required for the development of the thymus, as it controls mesenchymal-to-epithelial transition and epithelial cell proliferation in the thymus. ${ }^{50} \beta$-actin, an important cytoskeletal protein, seems to be overexpressed in actively moving cancer cells. ${ }^{51}$ In our experiments, we found that the three indicators were all significantly increased in tumor-bearing mice compared to normal mice (Table 5, Figure 5), which revealed that the existence of tumors could enhance the immune function and accelerate the proliferation and differentiation of thymocytes, and when the differentiation rate was higher than proliferation rate, thymic atrophy occurred.

In conclusion, H22 tumor cells would encourage the differentiation and maturation of thymocytes to enhance immune function, while unactivated $\mathrm{T}$ cells could not effectively inhibit the H22 solid tumors' growth or induce their apoptosis, then more unactivated mature $\mathrm{T}$ cells were produced and released from the thymus, causing a vicious cycle which finally led to thymic atrophy.

\section{Acknowledgments}

The study was supported by the Natural Science Foundation of Agriculture Department (number 201303082-3) and National Natural Science Foundation of China (number 31271975).

\section{Disclosure}

The authors report no conflicts of interest in this work.

\section{References}

1. Ge Q, Zhao Y. Evolution of thymus organogenesis. Dev Comp Immunol. 2013;39(1-2):85-90.

2. Francelin C, Paulino LC, Gameiro J, Verinaud L. Effects of Plasmodium berghei on thymus: high levels of apoptosis and premature egress of CD4(+)CD8(+) thymocytes in experimentally infected mice. Immunobiology. 2011;216(10):1148-1154.

3. Lima AC, Francelin C, Ferrucci DL, Stach-Machado DR, Verinaud L. Thymic alterations induced by Plasmodium berghei: expression of matrix metalloproteinases and their tissue inhibitors. Cell Immunol. 2012;279(1):53-59.

4. Radojevic K, Rakin A, Pilipovic I, et al. Effects of catecholamines on thymocyte apoptosis and proliferation depend on thymocyte microenvironment. J Neuroimmunol. 2014;272(1-2):16-28.

5. Riemann M, Andreas N, Fedoseeva M, et al. Central immune tolerance depends on crosstalk between the classical and alternative NFkappaB pathways in medullary thymic epithelial cells. J Autoimmun. 2017;81:54-67.

6. Li J, Liu C H, Wang F S. Thymosin alpha 1: biological activities, applications and genetic engineering production. Peptides. 2010;31(11): 2151-2158.

7. Goldstein AL, Goldstein AL. From lab to bedside: emerging clinical applications of thymosin $\alpha 1$. Expert Opin Biol Ther. 2009;9(5):593-608.
8. Naylor PH, Quadrini K, Garaci E, Rasi G, Hadden JW. Immunopharmacology of thymosin alpha1 and cytokine synergy. Ann NYAcad Sci. 2007;1112:235-244

9. Li W, Zhang Y, Zhang M, Huang G, Zhang Q. Wht4 is overexpressed in human pituitary adenomas and is associated with tumor invasion. J Clin Neurosci. 2014;21(1):137-141.

10. Lee J, Lim KT. SJSZ glycoprotein $(38 \mathrm{kDa})$ prevents thymus atrophy and enhances expression of IL-2 and IL-12 in diethylnitrosamine-induced hepatocarcinogenesis. Int Immunopharmacol. 2012;13(3):362-369.

11. Nakayama E, Shiratsuchi Y, Kobayashi Y, Nagata K. The importance of infiltrating neutrophils in SDF-1 production leading to regeneration of the thymus after whole-body X-irradiation. Cell Immunol. 2011;268(1):24-28.

12. Godet Y, Fabre E, Dosset M, et al. Analysis of spontaneous tumorspecific CD4 T-cell immunity in lung cancer using promiscuous HLA-DR telomerase-derived epitopes: potential synergistic effect with chemotherapy response. Clin Cancer Res. 2012;18(10): 2943-2953.

13. Zhang XY, Yang BY, Wang JY, Mo X, Zhang J, Hua ZC. FADD is essential for glucose uptake and survival of thymocytes. Biochem Biophys Res Commun. 2014;451(2):202-207.

14. Gao K, Li X, Zhang L, et al. Transgenic expression of IL-33 activates CD8 +, T cells and NK cells and inhibits tumor growth and metastasis in mice. Cancer Lett. 2013;335(2):463-471.

15. Hiraoka N. Tumor-infiltrating lymphocytes and hepatocellular carcinoma: molecular biology. Int J Clin Oncol. 2010;15(6):544-551.

16. Ghosh S, Sarkar M, Ghosh T, et al. Absence of CD4(+) T cell help generates corrupt CD8(+) effector T cells in sarcoma-bearing Swiss mice treated with NLGP vaccine. Immunol Lett. 2016;175:31-39.

17. Knocke S, Fleischmann-Mundt B, Saborowski M, Manns MP, Kühnel F, Wirth TC, Woller N. Tailored tumor immunogenicity reveals regulation of CD4 and CD8 T Cell responses against cancer. Cell Rep. 2016;17(9):2234-2246.

18. Wang M, Wang H, Tang Y, et al. Effective inhibition of a Strongylocentrotus nudus eggs polysaccharide against hepatocellular carcinoma is mediated via immunoregulation in vivo. Immunol Lett. 2011;141(1):74-82.

19. Du L, Yang YH, Wang YM, Xue CH, Kurihara H, Takahashi K. Antitumour activity of EPA-enriched phospholipids liposomes against S180 ascitic tumour-bearing mice. J Funct Foods. 2015;19:970-982.

20. Mo L, Chen Y, Li W, Guo S, Wang X, An H, Zhan Y. Anti-tumor effects of $(1 \rightarrow 3)$-beta-d-glucan from Saccharomyces cerevisiae in S180 tumorbearing mice. Int J Biol Macromol. 2017;95:385-392.

21. Xi S, Peng Y, Minuk GY, et al. The combination effects of ShenLing-Bai-Zhu on promoting apoptosis of transplanted H22 hepatocellular carcinoma in mice receiving chemotherapy. J Ethnopharmacol. 2016;190:1-12.

22. Chen F, Sun Y, Zheng SL, et al. Antitumor and immunomodulatory effects of ginsenoside Rh2 and its octyl ester derivative in $\mathrm{H} 22$ tumorbearing mice. J Funct Foods. 2017;32:382-390.

23. Ling N, Zhou X, Ji Y, Li W, Ji C, Qi Z. Immuno-modulatory and cellular antioxidant activities of kappa-selenocarrageenan in combination with Epirubicin in $\mathrm{H} 22$ hepatoma-bearing mice. Biomed Pharmacother. 2017;91:132-137.

24. Ying S, Wang J, Wang Y, et al. A novel mutant 10Ala/Arg together with mutant 144Ser/Arg of hepatitis B virus X protein involved in hepatitis $B$ virus-related hepatocarcinogenesis in HepG2 cell lines. Cancer Lett. 2016;371(2):285-291.

25. Zhang GL, Jiang L, Yan Q, Liu RH, Zhang L. Anti-tumor effect of matrine combined with cisplatin on rat models of cervical cancer. Asian Pac J Trop Med. 2015;8(12):1055-1059.

26. Liu D, Yang P, Zhang YQ. Water-soluble extract of Saxifraga stolonifera has anti-tumor effects on Lewis lung carcinoma-bearing mice. Bioorg Med Chem Lett. 2016;26(19):4671-4678.

27. Hu B, Wang J, Guo Y, et al. Pre-clinical toxicity and immunogenicity evaluation of a MUC1-MBP/BCG anti-tumor vaccine. Int Immunopharmacol. 2016;33:108-118. 
28. Iwai H, Inaba M. Fetal thymus graft prevents age-related hearing loss and up regulation of the IL-1 receptor type II gene in CD4(+) T cells. J Neuroimmunol. 2012;250(1-2):1-8.

29. Valanciute A, Mozuraite R, Balnyte I, Didziapetriene J, Matusevicius $\mathrm{P}$, Stakisaitis D. Sodium valproate effect on the structure of rat glandule thymus: Gender-related differences. Exp Toxicol Pathol. 2015;67(7-8):399-406.

30. Kaiserlian D, Savino W, Hassid J, Dardenne M. Studies of the thymus in mice bearing the Lewis lung carcinoma. III. Possible mechanisms of tumor-induced thymic atrophy. Clin Immunol Immunopathol. 1984;32(3):316-325.

31. Mandal D, Bhattacharyya A, Lahiry L, Choudhuri T, Sa G, Das T. Failure in peripheral immuno-surveillance due to thymic atrophy: importance of thymocyte maturation and apoptosis in adult tumor-bearer. Life Sci. 2005;77(21):2703-2716.

32. Mandal D, Lahiry L, Bhattacharyya A, Bhattacharyya S, Sa G, Das T. Tumor-induced thymic involution via inhibition of IL-7R $\alpha$ and its JAKSTAT signaling pathway: protection by black tea. Int Immunopharmacol. 2006;6(3):433-444.

33. Young MRI. Redirecting the focus of cancer immunotherapy to premalignant conditions. Cancer Lett. 2017;391:83-88.

34. Karayannopoulou M, Anagnostou T, Margariti A, Kostakis C, KritsepiKonstantinou M, Psalla D, Savvas I. Evaluation of blood T-lymphocyte subpopulations involved in host cellular immunity in dogs with mammary cancer. Vet Immunol Immunopathol. 2017;186:45-50.

35. Kavanagh ME, Conroy MJ, Clarke NE, et al. Impact of the inflammatory microenvironment on T-cell phenotype in the progression from reflux oesophagitis to Barrett oesophagus and oesophageal adenocarcinoma. Cancer Lett. 2016;370(1):117-124.

36. Sukumar M, Kishton RJ, Restifo NP. Metabolic reprograming of antitumor immunity. Curr Opin Immunol. 2017;46:14-22.

37. Lustig A, Weeraratna AT, Wood WW 3rd, et al. Transcriptome analysis of age-, gender- and diet-associated changes in murine thymus. Cell Immunol. 2007;245(1):42-61.

38. Mastino A, Piacentini M, Grelli S, et al. Induction of apoptosis in thymocytes by prostaglandin E2 in vivo. Dev Immunol. 1992;2(4):263-271.

39. Lopez DM, Lopez-Cepero M, Watson G A, Ganju A, Sotomayor E, Fu $\mathrm{XX}$. Modulation of the immune system by mammary tumor-derived factors. Cancer Invest. 1991;9(6):643-653.
40. Prins RM, Graf MR, Merchant RE, Black KL, Wheeler CJ. Thymic function and output of recent thymic emigrant $T$ cells during intracranial glioma progression. J Neurooncol. 2003;64(1-2):45-54.

41. Shanker A, Singh SM, Sodhi A. Ascitic growth of a spontaneous transplantable T cell lymphoma induces thymic involution. 1. Alterations in the CD4/CD8 distribution in thymocytes. Tumor Biol. 2000;21(5):288-298.

42. Hadden JW. Immunodeficiency and cancer: prospects for correction. Int Immunopharmacol. 2003;3(8):1061-1071.

43. Thomas E, Smith DC, Lee MY, Rosse C. Induction of granulocytic hyperplasia, thymic atrophy, and hypercalcemia by a selected subpopulation of a murine mammary adenocarcinoma. Cancer Res. 1985;45(11 Pt 2):5840-5844.

44. Kuss I, Hathaway B, Ferris RL, Gooding W, Whiteside TL. Decreased absolute counts of $\mathrm{t}$ lymphocyte subsets and their relation to disease in squamous cell carcinoma of the head and neck. Clin Cancer Res. 2004;10(11):3755-3762.

45. Saito T, Dworacki G, Gooding W, Lotze MT, Whiteside TL. Spontaneous apoptosis of CD8+ T lymphocytes in peripheral blood of patients with advanced melanoma. Clin Cancer Res. 2000;6(4):1351-1364.

46. Xu L, Lin Y, Yao D, et al. Tumor antigen-specific CD8+, T cells are negatively regulated by PD-1 and Tim-3 in human gastric cancer. Cell Immunol. 2017;313:43-51.

47. Fesenkova V, Sultan H, Celis E. CD4 T Cells in antitumor immunity. Encyclopedia of Immunobiology. 2016;4:441-450.

48. Yuan C, Zheng Y, Zhang B, et al. Thymosin alphal promotes the activation of myeloid-derived suppressor cells in a Lewis lung cancer model by upregulating Arginase 1. Biochem Biophys Res Commun. 2015;464(1):249-255.

49. Liu D, Yu Z, Yin J, et al. Effect of ulinastatin combined with thymosin alpha1 on sepsis: a systematic review and meta-analysis of Chinese and Indian patients. J Crit Care. 2017;39:259-266.

50. Caprioli A, Villasenor A, Wylie LA, et al. Wnt4 is essential to normal mammalian lung development. Dev Biol. 2015;406(2):222-234.

51. Simiczyjew A, Mazur Antonina J, Ampe C, Malicka-Błaszkiewicz M, van Troys M, Nowak D. Active invadopodia of mesenchymally migrating cancer cells contain both $\beta$ and $\gamma$ cytoplasmic actin isoforms. Exp Cell Res. 2015;339(2):206-219.
Cancer Management and Research

\section{Publish your work in this journal}

Cancer Management and Research is an international, peer-reviewed open access journal focusing on cancer research and the optimal use of preventative and integrated treatment interventions to achieve improved outcomes, enhanced survival and quality of life for the cancer patient. The manuscript management system is completely online and includes

\section{Dovepress}

a very quick and fair peer-review system, which is all easy to use. Visit http://www.dovepress.com/testimonials.php to read real quotes from published authors. 